(Siddiqui and Kerr, 1971). Histological methods have been only partly quantitative and serial biopsy specimens have not been obtained. Ellis and Peart (1971) emphasized in their description of "Newcastle dialysis bone disease" that in the course of time on dialysis loss of bone and defective mineralization become more severe, whereas osteitis fibrosa diminishes. Our results differ in this respect, though the incidence of osteitis fibrosa was low in our study, perhaps because the incidence of predialysis osteodystrophy in general is lower in Oxford than in Newcastle.

The conversion of vitamin $D$ to its active metabolite 1,25 dihydroxycholecalciferol is believed to occur specifically in the kidney (Fraser and Kodicek, 1970). Binephrectomized patients might be expected, therefore, to show evidence of a greater susceptibility to osteomalacia than other dialysed patients. In this series three patients were binephrectomized. Osteomalacia was observed in all three before nephrectomy, but progress of bone disease thereafter could not be distinguished from the pattern observed in un-nephrectomized dialysed patients. Indeed, in one anephric patient vitamin D treatment was followed by the appearance of osteitis fibrosa and healing of osteomalacia.

The cause of bone loss, possibly beginning in the terminal phases of chronic renal failure and certainly extending into the period of dialysis, in conjectural. Immobilization may be very important, since the observed changes were maximal in the first year of dialysis treatment when some patients spent long periods in hospital. In our series bone loss was apparently not influenced by parathyroidectomy (four patients), and it is probable that the parathyroids have no important role in the development of osteoposoris in dialysed patients (Harrison, 1968).

Unidentified factors in tap-water removed by deionizers probably contribute to osteomalacia and may be responsible for the pronounced regional variations in the incidence of "dialysis bone disease" (Posen et al., 1972).

We acknowledge the help of Dr. F. W. Wadia and Dr. G. D. Nicholson with the bone biopsies and thank the patients in this study for their willing co-operation.

\section{References}

Bishop, M. C., Ledingham, J. G. G., Oliver, D. O., and Smith, R. (1971). Proceedings of Eighth Congress of the European Dialysis and Transplant Association, p. 122. London, Pitman Medical.

Byers, P. D., and Smith, R. (1971). Quarterly fournal of Medicine, 40, 471. Dixon, W. J., and Massey, F. J. (1951). Introduction to Statistical Analysis, p. 16. New York, McGraw Hill.

Dunnill, M. S. (1968). In Recent Advances in Clinical Pathology, ed. S. C. Dyke, Series 5, p. 401. London, Churchill.

Dunnill, M. S., Anderson, J. A., and Whitehead, R. (1969). Fournal of Pathology and Bacteriology, 94, 275.

Ellis, H. A., and Peart, K. M. (1971). Nephron, 8, 402.

Follis, R. H., and Jackson, D. (1943). Bulletin of the fohns Hopkins Hospital, 72,232 .

Fournier, A. E., Arnaud, C. D., Johnson, W. J., Taylor, W. F., and Goldsmith, R. S. (1971). Fournal of Clinical Investigation, 50, 599.

Fraser, D. R., and Kodicek, E. (1970). Nature, 228, 769.

Freeman, R. B., Maher, J. F., O'Connell, J. M. B., and Schreiner, G. E. (1967). In Proceedings of Third International Congress of Nephrology, ed. G. Schreiner, vol. 3, p. 316. New York, Karger.

Garner, A., and Ball, J. (1966). Fournal of Pathology and Bacteriology, $91,545$.

Harris, W. H., and Heaney, R. P. (1969). New England fournal of Medicine, 280,193 .

Harrison, A. R. (1968). Proceedings of Fifth Congress of the European Dialysis and Transplant Association, p. 404. Amsterdam, Excerpta Medica.

Jowsey, J., Coburn, J. W., Massry, S. G., and Kleeman, C. R. (1969). Archives of Internal Medicine, 124, 539.

Katz, A. I., Hampers, C. L., and Merrill, J. P. (1969). Medicine, 48, 333.

Kaye, M., Chatterjee, G., and Cohen, G. F. (1969). Proceedings of Fourth International Congress of Nephrology, 3, 151 .

Kim, D., et al. (1968). Transactions of the American Society for Artificial Internal Organs, 14, 367.

Kleeman, C. R., Massry, S. G., Coburn, J. W., and Popovtzer, M. M. (1970). Clinical Orthopaedics, 86, 210.

Kyle, L. H. (1969). Annual Review of Medicine, 20, 259.

Pendras, J. P. (1969). Archives of Internal Medicine, 124, 312.

Pendras, J. P., and Erickson, R. V. (1966). Annals of Internal Medicine, 64, 293.

Posen, G. A., et al. (1972). Paper read to Association of Physicians of Great Britain and Ireland, 24 March.

Raisz, L. G., and Niemann, I. (1969). Endocrinology, 85, 446

Ritz, E., Krempien, B., Kuhns, H., and Henck, F. (1971). Israel fournal of Medical Science, 7, 520.

Siddiqui, J., and Kerr, D. N. S. (1971). British Medical Bulletin, 29, 153. Stanbury, S. W. (1969). Fournal of Bone and foint Surgery, 51B, 576.

Stanbury, S. W. (1971). In Phosphate et Metabolisme Phosphocalique, ed. D. J. Hioco, p. 187. Paris, Sandoz.

Stanbury, S. W., and Lumb, G. A. (1966). Quarterly fournal of Medicine, 35,1 .

Williams, J. A., and Nicholson, G. I. (1963). Lancet, 1, 1408.

Woods, C. G., Paterson, C. R., Morgan, D. B., and Gossmann, H. H (1968). Fournal of Pathology and Bacteriology, 95, 441.

Woods, C. G., Bishop, M. C., and Nicholson, G. D. (1972). Fournal of Pathology. In press.

\title{
The Risk of Rh Isoimmunization in Ruptured Tubal Pregnancy
}

\author{
J. KATZ, R. G. MARCUS
}

British Medical fournal, 1972, 3, 667-669

\section{Summary}

In $9(24 \%)$ out of 38 African women who had suffered a ruptured tubal pregnancy significant numbers of fetal erythrocytes (5 or more per 150,000 maternal cells) were found in the maternal circulation. This is a higher incidence than occurs after abortion and indicates that rupture of a tubal pregnancy is a potential source of $R h$ isoimmunization. The finding of fetal cells in the peritoneal cavity suggests that this is the main source of the fetal blood found in the maternal circulation. At opera-

\footnotetext{
University of the Witwatersrand and South African Institute for Medical Research, Johannesburg, South Africa

J. KATZ, M.B., F.C.PATH. (S.A.), Senior Haematologist

University of the Witwatersrand, Johannesburg, South Africa R. G. MARCUS, M.B., M.R.C.o.G., Registrar in Obstetrics and Gynaecology
}

tion on Rh-negative patients with ruptured tubal pregnancies, therefore, complete removal of the peritoneal blood should be attempted and the blood recovered should never be transfused into the patient, who should always receive prophylactic $\mathrm{Rh}$ immunoglobulin.

\section{Introduction}

The prophylactic administration of $\mathrm{Rh}$ immunoglobulin is an accepted method of prevention of $\mathrm{Rh}$ isoimmunization. Clinical trials have shown that more than $90 \%$ of $\mathrm{Rh}$-negative primiparae are protected if the recommended dose of $\mathrm{Rh}$ immunoglobulin is injected within 72 hours of the birth of a Rh-positive baby (Combined Study, 1971; Woodrow et al., 1971). In addition to full-term pregnancy abortion has been implicated as a cause of $\mathrm{Rh}$ isoimmunization (Matthews and Matthews, 1969; Katz, 1969), and it is recommended that all Rh-negative women who have aborted should receive $\mathrm{Rh}$ immunoglobulin prophylactically (Freda et al., 1970; Murray and Barron, 1971). 
Furthermore, small fetomaternal haemorrhages occur during pregnancy, particularly in the third trimester, and this prompted Zipursky and Israels (1967) to administer $\mathrm{Rh}$ immunoglobulin to $\mathrm{Rh}$-negative women in the last three months of pregnancy.

Another possible indication for $\mathrm{Rh}$ prophylaxis which has not, to our knowledge, previously been studied is intraperitoneal rupture of a tubal pregnancy. Review of the literature disclosed only one reported case of $\mathrm{Rh}$ isoimmunization caused by a ruptured tubal pregnancy (Aborjaily, 1969). In order to evaluate the risk of $\mathbf{R h}$ isoimmunization in tubal pregnancy we have investigated the incidence and amount of fetomaternal haemorrhage occurring after intraperitoneal rupture of tubal pregnancies.

\section{Patients and Methods}

Thirty-eight African women admitted to the Baragwanath Hospital, Johannesburg, with ruptured tubal pregnancies were studied. The duration of pregnancy before rupture varied from 6 to 10 weeks and the patients were operated on within four hours of their admission. Venous blood specimens were collected before operation in 20 cases, and within 24 hours after the operation in all 38. In 21 cases intraperitoneal blood was collected at operation. Fetal cell counts were performed on the blood specimens and the results were compared with those obtained from the venous blood of 40 non-pregnant African women. The latter group comprised 18 healthy subjects and 22 hospital patients.

For the fetal cell counts 3-ml volumes of venous and peritoneal blood were collected into tubes containing dried Sequestrene (sodium acetate) and stored at $4^{\circ} \mathrm{C}$. Blood films were prepared from these samples within 72 hours of collection. The films were treated by the acid elution technique of Kleihauer and Betke (1957) and the fetal cell score was determined by the method of Woodrow et al. (1965). Duplicate films from each sample were examined. Positive controls (cord or infant's blood) were included with each batch of samples studied. The presence of five or more fetal cells per 150,000 maternal cells in the venous blood samples, was considered to indicate a significant fetomaternal haemorrhage (Mollison, 1968). The intraperitoneal

Fetal Cell Counts (No. of Fetal Cells per 150,000 Maternal Cells) in 38 Patients with Ruptured Tubal Pregnancy

\begin{tabular}{|c|c|c|c|}
\hline \multirow{2}{*}{$\begin{array}{l}\text { Case } \\
\text { No. }\end{array}$} & \multicolumn{2}{|c|}{ No. in Systemic Circulation } & \multirow{2}{*}{$\begin{array}{l}\text { No. in Blood from } \\
\text { Peritoneal Cavity }\end{array}$} \\
\hline & Before Operation & After Operation & \\
\hline $\begin{array}{r}1 \\
2 \\
3 \\
4 \\
5 \\
6 \\
7 \\
8 \\
9 \\
10 \\
11 \\
12 \\
13 \\
14 \\
15 \\
16 \\
17 \\
18 \\
19 \\
20 \\
21 \\
22 \\
23 \\
24 \\
25 \\
26 \\
27 \\
28 \\
29 \\
30 \\
31 \\
32 \\
33 \\
34 \\
35 \\
36 \\
37 \\
38\end{array}$ & $\begin{array}{c}21 \\
12 \\
2 \\
\text { N.T. } \\
\text { ” } \\
\text { "2 } \\
10 \\
\text { N.T. } \\
0 \\
0 \\
1 \\
0 \\
0 \\
\text { N.T. } \\
0 \\
1 \\
0 \\
0 \\
0 \\
0 \\
\text { N.T. } \\
\text { ” } \\
\text { ” } \\
\text { ” } \\
\text { " } \\
\text { N.T. } \\
\text { N. } \\
\text { ” } \\
\text { "1 } \\
1 \\
\text { N.T. } \\
\text { ” }\end{array}$ & $\begin{array}{r}14 \\
9 \\
1 \\
4 \\
2 \\
6 \\
3 \\
9 \\
3 \\
2 \\
1 \\
2 \\
0 \\
0 \\
1 \\
0 \\
0 \\
0 \\
0 \\
0 \\
0 \\
8 \\
7 \\
6 \\
5 \\
5 \\
4 \\
4 \\
4 \\
4 \\
3 \\
2 \\
2 \\
2 \\
1 \\
0 \\
0 \\
0\end{array}$ & 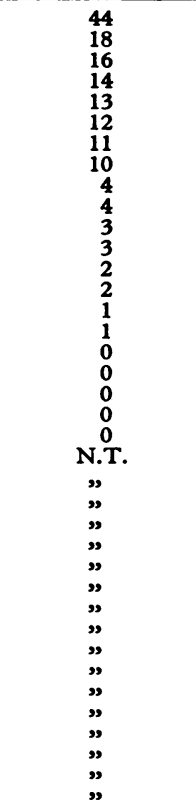 \\
\hline
\end{tabular}

N.T. $=$ Not tested fetal cell count was recorded as the number of fetal cells per 150,000 maternal erythrocytes present in the peritoneal cavity.

\section{Results}

The numbers of fetal cells detected in the patients' blood samples are shown in the Table. A fetal cell score of 5 or more per 150,000 was present in 4 out of 20 preoperative venous samples and in $9(23.7 \%)$ out of 38 postoperative venous samples. Fetal cells were detected in 16 of the 21 peritoneal blood samples examined. The patients with the highest intraperitoneal counts showed the greatest numbers of fetal cells in the maternal circulation $(r=0.03146, P<0.001)$. No estimate of the total amount of fetal blood present intraperitoneally could be made as the volume of blood in the peritoneal cavity was not measured. The fetal counts in postoperative venous blood samples were slightly lower than those in the preoperative samples, probably as the result of a dilution effect, since blood transfusions were administered during and after the operation. Four of the patients with significant amounts of fetal blood in the maternal circulation after the operation also had fetal blood in the peritoneal cavity.

In the $\mathbf{4 0}$ non-pregnant African women studied the maximum number of "stained cells" resembling fetal cells detected in the blood by the acid elution technique was 2 per 150,000 erythrocytes. In $5(12.5 \%)$ of the 40 subjects the "fetal cell" score was 1 or 2 per 150,000 .

\section{Discussion}

The incidence of hereditary persistence of the fetal haemoglobin gene in the South African Bantu has been estimated by Jenkins and Stevens (1970) to be of the order of 1 in 1,000, which is similar to that reported by Bradley et al. (1961) and Olivia and Myerson (1961) in U.S. Negroes. Furthermore the incidence of an occasional "fetal cell" in the circulation of non-pregnant adults in the present study $(12.5 \%)$ does not differ significantly from the figures of $18 \%$ reported by Tepper and Verso (1964), $12 \%$ by Sullivan and Jennings (1966), and $6.7 \%$ by Woodrow and Finn (1966) for healthy adults or hospitalized inpatients. There is therefore no evidence of an increased incidence of high levels of fetal haemoglobin in the local African population. If anything, the incidence is possibly less than in other population groups, for the thalassaemia syndromes, not infrequent in local whites, Indians, and Chinese, have yet to be seen in the African.

Woodrow and Finn (1966) suggested that a fetal cell count of 3 per 150,000 in the maternal circulation should be regarded as evidence of fetomaternal haemorrhage. In the present study a score of 5 or more was considered to be significant in view of the finding of 1 or 2 darkly staining cells per 150,000 in control subjects. The high incidence $(23.7 \%)$ of significant fetomaternal haemorrhage found after a ruptured tubal pregnancy indicates that this may be an important source of $\mathrm{Rh}$ isoimmunization. This figure is significantly higher $(P<0.02)$ than that found after abortion by Katz (1969) (4 out of 81 patients; $4.9 \%$ ). Thus the risk of $\mathrm{Rh}$ isoimmunization in ruptured tubal pregnancy is greater than in abortion. The incidence of significant fetomaternal haemorrhage after tubal rupture is similar to that recorded postpartum (Zipursky et al., 1963; Cohen and Zuelzer, 1964; Woodrow et al., 1965).

The finding of fetal blood in the maternal circulation probably reflects the fact that erythrocytes introduced into the peritoneal cavity are absorbed into the systemic circulation (Clausen, 1938; Hedenstedt, 1947; Waite et al., 1956). The correlation between the venous and peritoneal fetal cell counts suggests that the absorption of cells from the peritoneal cavity is the major source of fetal erythrocytes in the maternal circulation, though it does not exclude the possibility that fetal erythrocytes may enter the maternal circulation at the site of tubal rupture. 
The highest fetal cell count found in the maternal circulation was 14 per 150,000 , equivalent to approximately $0.7 \mathrm{ml}$ of fetal blood, an antigenic dose sufficient to produce primary immunization (Zipursky et al., 1965). Evidence of $\mathrm{Rh}$ isoimmunization after tubal pregnancy with a severely affected infant has been repurted in a single case (Aborjaily, 1969). We have seen a similar patient who developed an $\mathrm{Rh}$ antibody titre of $1 / 64$ in her second pregnancy, a previous tubal pregnancy having ended in intraperitoneal rupture. The baby was born jaundiced and required two exchange transfusions for hyperbilirubinaemia associated with a Coombs-positive haemolytic anaemia. As the antibody response to an antigen is dose-dependent the high $R h$ titre in these two immunized patients and the severity of the $\mathrm{Rh}$ disease in the infants suggest that the amount of fetal blood which had passed into the maternal circulation must have been relatively large.

The significant incidence of fetomaternal haemorrhage recorded in this study indicates that all $\mathrm{Rh}$-negative women with ruptured tubal pregnancies require prophylactic $\mathbf{R h}$ immunoglobulin. We also suggest that in such cases the peritoneal blood should be aspirated completely at laparotomy whenever possible so as to remove the fetal blood cells which may be a source of antigen and may produce immunization if left in situ. The practice of transfusing a patient with her own blood recovered from the peritoneal cavity should be avoided if she is Rh-negative.

We thank Professor J. Metz for his helpful criticism and advice; the director, South African Institute for Medical Research, for facilities to carry out this study; Professor L. van Dongen, Dr. A. Rubin, and the staff of the obstetrics and gynaecology department of the Baragwanath Hospital for allowing us to study patients under their care; and Dr. C. Kniep for permission to make this report. Due acknowledgement is made to the Atomic Energy Board and South African Medical Research Council for help and support enabling the research to be undertaken.

\section{References}

Aboriaily, A. N. (1969). New England fournal of Medicine, 281, 1076.

Bradley, T. B., jun., Brauner, J. N., and Conley, C. L. (1961). Bulletin of the fohns Hopkins Hospital, 108, 1242.

Clausen, J. (1938). Acta Pathologica et Microbiologica Scandinavica, Suppl. No. $37, p$. 134.

Cohen, R., and Zuelzer, W. W. (1964). Vox Sanguins, 9, 75.

Combined Study from Centres in England and Baltimore (1971). British Medical fournal, 2, 607.

Freda, V. J., Gorman, J. G., Galen, R. S., and Treacy, N. (1970). Lancet, 2,

Hedenstedt, S. (1947). Acta Chirurgica Scandinavica, 95, Suppl. No. 128,

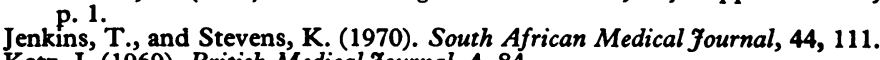
Katz, J. (1969). British Medical Fournal, 4, 84.

Kleihauer, E., Braun, H., and Betke, K. (1957). Klinische Wochenschrift, 35, 637.

Matthews, C. D., and Matthews, A. E. B. (1969). Lancet, 1, 694.

Mollison, P. L. (1968). British fournal of Haematology, 14, 1 .

Murray, S., and Barron, S. L. (1971). British Medical fournal, 3, 90.

Olivia, J., and Myerson, R. M. (1961). American Fournal of the Medical Sciences, 241, 215 .

Sullivan, J. F., and Jennings, E. R. (1966). fournal of Clinical Pathology, 46, 36.

Tepper, V., and Verso, M. L. (1964). Medical fournal of Australia, 2, 585. Waite, M. E., Colucci, D. D., and Glaser, J. (1956). American Yournal of Diseases of Children, 91,561 .

Woodrow, J. C., et al. (1965). British Medical fournal, 1, 279

Woodrow, J. C., and Finn, R. (1966). British fournal of Haematology, 12, 297.

Woodrow, J. C., Clarke, C. A., McConnell, R. B., Towers, S. H., and Donohoe, W. T. A. (1971). British Medical fournal, 2, 610.

Zipursky, A., and Israels, L. G. (1967). Canadian Medical Association fournal, $97,1245$.

Zipursky, A., Pollock, J., Neelands, P., Chown, B., and Israels, L. G. (1963). Lancet, 2, 493.

Zipursky, A., Pollock, J., Chown, B., and Israels, L. G. (1965). In Birth Defects, Original Article Series, ed. D. Bergsma, Vol. 1, p. 84. New York, National Association, March of Dimes.

\title{
Galactorrhoea: Successful Treatment with Reduction of Plasma Prolactin Levels by Brom-ergocryptine
}

\author{
G. M. BESSER, LYNNE PARKE, C. R. W. EDWARDS, ISABEL A. FORSYTH, A. S. MCNEILLY
}

British Medical fournal, 1972, 3, 669-672

\section{Summary}

In five patients with inappropriate lactation and amenorrhoea or impotence brom-ergocryptine was found to suppress the lactation and to diminish the raised plasma prolactin levels. The responses to treatment suggest that there may be an inverse relationship between prolactin secretion and gonadotrophin secretion in man.

\section{Introduction}

In most patients inappropriate lactation is accompanied by raised plasma levels of prolactin. Inappropriate lactation may be due to hypothalamic or pituitary disease, or to the action of

St. Bartholomew's Hospital, London E.C.1

G. M. BESSER, M.D., M.R.C.P., Senior Lecturer in Endocrinology

C. R. W. EDWARDS, M.B., M.R.C.P., Lecturer in Medicine

A. S. MCNEILLY, B.SC., PH.D., Research Lecturer in Chemical Pathology

National Institute for Research in Dairying, Shinfield, Berks.

LYNNE PARKE, B.sc., Scientific Officer

ISABEL A. FORSYTH, M.A., D.PHIL., Principal Scientific Officer psychoactive drugs (Forsyth et al., 1971; Kleinberg and Frantz, 1971; Besser and Edwards, 1972). This hyperprolactinaemia is usually accompanied by reduced plasma gonadotrophin levels and amenorrhoea in women and impotence in men. There may be a reciprocal mechanism controlling secretion of prolactin and the gonadotrophins (Ben-David et al., 1971; Kamberi, et al., 1971a, 1971b). Pathological galactorrhoea is difficult to treat, though if it follows medication with the contraceptive pill it may occasionally respond to clomiphene. We now report the use of the ergot alkaloid 2-Br-alpha-ergocryptine (referred to in this paper as brom-ergocryptine) in five patients with galactorrhoea and show that it rapidly lowers plasma prolactin levels leading to cessation of lactation and, with the exception of a patient who had undergone partial hypophysectomy, to resumption of normal gonadal function with menstruation or potency. Lutterbeck et al. (1971) previously reported preliminary clinical studies and termination of galactorrhoea in three non-puerperal women on brom-ergocryptine, and Varga et al. (1972) showed that it inhibits puerperal lactation.

\section{Methods}

Prolactin Bioassay.-The lactogenic response obtained in cultured mammary tissue of pseudopregnant rabbits was used 